\title{
EVALUASI SIFAT KIMIA TANAH MENURUT JARAK DARI SUNGAI DI DAERAH PASANG SURUT KECAMATAN KOTA BESI, KOTAWARINGIN TIMUR, KALIMANTAN TENGAH
}

(Evaluation of Soil Chemical Properties by Distance from the River in The Tidal Land Area of Kota Besi District, East Kotawaringin, Central Borneo)

\author{
Basuki, ${ }^{1)}$ Zubaidah, S., ${ }^{1)}$ Husin ${ }^{1)}$
}

1)Jurusan Budidaya Pertanian, Fakultas Pertanian, Universitas Palangka Raya

Telpon : 081349756847; E-mail : basuki@agr.upr.ac.id

Diterima : 25/02/2018

Disetujui : 18/04/2018

\begin{abstract}
This study aims to determine the effect of the location distance from the river bank and the depth of soil layer to the soil chemical properties in the tidal land area. The study was conducted in April until June 2016 in the tidal areas of Bajarum village, District of Kota Besi, East Kotawaringin, Central Borneo Province. The study used survey methods and soil sampling in the field, analysis of soil samples in the laboratory and continued with analysis and description of data. Soil sampling was conducted at distances of 250, 500, 750, 1.000, 1.250 and 1.500 meters from the Mentaya river bank at two depth soil layers $(0-25 \mathrm{~cm}$ and $25-50 \mathrm{~cm})$. The soil chemistry properties analyzed included $\mathrm{pH}$, cation exchange capacity (CEC), base saturation, organic $\mathrm{C}, \mathrm{N}$ total, total $\mathrm{P}_{2} \mathrm{O}_{5}$, total $\mathrm{K}_{2} \mathrm{O}$, alumunium and hydrogen exchangeable and soil fertility status. The results of study showed that: (1) The further distance of soil from the position of Mentaya river bank there is an increase of organic $\mathrm{C}$, total $\mathrm{P}_{2} \mathrm{O}_{5}$, total $\mathrm{N}$, total $\mathrm{K}_{2} \mathrm{O}, \mathrm{pH}, \mathrm{CEC}$, base saturation and soil fertility status, on the contrary showed a decrease in alumunium and hydrogen exchangeable. The limiting factor of soil fertility is mainly the low base saturation, besides that at some point observation also due to low CEC, total $\mathrm{P}_{2} \mathrm{O}_{5}$ and total $\mathrm{K}_{2} \mathrm{O}$. (2) Sub soil layer $(25-50) \mathrm{cm}$ has a higher $\mathrm{pH}$ and base saturation values compared to topsoil layer $(0-25) \mathrm{cm}$. In contrast, topsoil layer has CEC, alumunium and hydrogen exchangeable, total $\mathrm{P}_{2} \mathrm{O}_{5}$, total $\mathrm{K}_{2} \mathrm{O}$, total $\mathrm{N}$ and organic $\mathrm{C}$ values higher than sub soil layer.
\end{abstract}

\section{Keywords: distance from river, tidal soil, soil chemical properties.}

\begin{abstract}
ABSTRAK
Penelitian ini bertujuan untuk mengetahui pengaruh jarak lokasi dari pinggir sungai dan kedalaman lapisan tanah terhadap sifat kimia tanah di lahan pasang surut. Penelitian dilaksanakan bulan April hingga Juni 2016 di daerah pasang surut Desa Bajarum, Kecamatan Kota Besi, Kabupaten Kotawaringin Timur, Provinsi Kalimantan Tengah. Penelitian dilakukan dengan survey dan pengambilan sampel tanah di lapangan, analisis sampel tanah di laboratorium dan dilanjutkan dengan analisis dan deskripsi data. Pengambilan sampel tanah dilakukan pada jarak 250, 500, 750, 1.000, 1.250 dan 1.500 meter dari pinggir sungai Mentaya pada dua kedalaman lapisan tanah $(0-25 \mathrm{~cm}$ dan $25-50 \mathrm{~cm})$. Sifat kimia tanah yang dianalisis meliputi $\mathrm{pH}$, kapasitas tukar kation (KTK), kejenuhan basa (KB), $\mathrm{C}$ organik, $\mathrm{N}$ total, $\mathrm{P}_{2} \mathrm{O}_{5}$ total, $\mathrm{K}_{2} \mathrm{O}$ total, alumunium dan hidrogen dapat dipertukarkan dan status kesuburan tanah. Hasil penelitian menunjukkan bahwa: (1) Semakin jauh jarak tanah dari posisi pinggir sungai Mentaya terdapat peningkatan $\mathrm{C}$ organik, $\mathrm{P}_{2} \mathrm{O}_{5}$ total, $\mathrm{N}$ total, $\mathrm{K}_{2} \mathrm{O}$ total, pH, KTK, KB dan status kesuburan tanah. Sebaliknya terjadi penurunan kandungan alumunium dan hidrogen dapat dipertukarkan (Al-dd dan H-dd). Faktor pembatas kesuburan tanah terutama berupa rendahnya kejenuhan basa $(\mathrm{KB})$, disamping itu pada beberapa titik pengamatan juga disebabkan karena rendahnya KTK, $\mathrm{P}_{2} \mathrm{O}_{5}$ total dan $\mathrm{K}_{2} \mathrm{O}$ total. (2) Tanah lapisan bawah $(25-50) \mathrm{cm}$ mempunyai nilai $\mathrm{pH}$ dan $\mathrm{KB}$ lebih tinggi dibandingkan dengan tanah lapisan atas $(0-25) \mathrm{cm}$. Sebaliknya tanah lapisan atas mempunyai nilai KTK, Al-dd, H-dd, $\mathrm{P}_{2} \mathrm{O}_{5}$ total, $\mathrm{K}_{2} \mathrm{O}$ total, $\mathrm{N}$ total dan $\mathrm{C}$ organik lebih tinggi dibandingkan dengan tanah lapisan bawah.
\end{abstract}

Kata Kunci : jarak dari sungai, tanah pasang surut, sifat kimia tanah 


\section{PENDAHULUAN}

Lahan rawa adalah lahan yang tergenang secara terus menerus akibat drainase buruk. Lahan rawa dibagi menjadi dua yaitu rawa lebak dan rawa pasang surut. Rawa lebak merupakan wilayah daratan yang mempunyai genangan hampir sepanjang tahun, minimal selama tiga bulan dengan tinggi genangan minimal $50 \mathrm{~cm}$. Sedangkan jika kedudukannya menjorok masuk jauh dari muara laut/sungai besar disebut rawa pedalaman (Noor, 2007).

Lahan rawa pasang surut merupakan suatu wilayah rawa yang dipengaruhi oleh gerakan pasang surut air laut yang secara berkala mengalami luapan air pasang. Jadi lahan rawa pasang surut dapat dikatakan sebagai lahan yang memperoleh pengaruh pasang surut air laut atau sungai-sungai sekitarnya. Bila musim penghujan lahan-lahan ini tergenang air sampai satu meter diatas permukaan tanah, tetapi bila musim kering bahkan permukaan air tanah menjadi lebih besar $50 \mathrm{~cm}$ di bawah permukaan tanah. Berdasarkan tipe luapan lahan pasang surut dibagi menjadi 4 yaitu 1) tipe luapan A, terluapi air pasang baik pasang besar maupun kecil, 2) tipe luapan B, hanya terluapi air pada pasang besar saja, 3) tipe luapan $\mathrm{C}$, tidak terluapi air pasang tapi kedalaman air tanahnya $<50 \mathrm{~cm}, 4)$ tipe luapan $\mathrm{D}$, tidak terluapi air pasang surut kedalaman air tanahnya $>50 \mathrm{~cm}$ (Adhi et al., 1992).

Tipologi lahan pasang surut dikelompokkan ke dalam empat kelompok yaitu lahan potensial, lahan sulfat masam, lahan gambut dan lahan salin. Lahan potensial merupakan wilayah lahan pasang surut yang tanahnya mempunyai lapisan sulfidik, berkadar pirit kurang dari $2 \%$ dan lapisan tersebut berada pada kedalaman lebih dari $50 \mathrm{~cm}$ dari permukaan tanah. Lahan sulfat masam yaitu wilayah lahan pasang surut yang tanahnya mempunyai lapisan sulfidik yang berkadar lebih dari $2 \%$, lapisan tersebut berada pada kedalaman kurang dari $50 \mathrm{~cm}$ dari permukaan tanah. Lahan gambut/bergambut adalah lahan yang mempunyai lapisan gambut dan berdasarkan ketebalan gambutnya lahan ini dibagi kedalam empat sub tipologi yaitu lahan bergambut, gambut dangkal, gambut dalam dan gambut sangat dalam, umumnya lahan gambut kahat beberapa unsur hara mikro yang ketersediaannya sangat penting untuk pertumbuhan dan pekermbangan tanaman (Manwan et al.,1992). Lahan salin merupakan wilayah yang terkena intrusi air asin. Wilayah ini umumnya berada lebih dekat ke laut dan termasuk tipe luapan A atau peralihan A ke B, pada musim kemarau masih dapat terluapi air pasang. Akibatnya, pada musim kemarau, air asin dapat masuk pada wilayah ini. Kandungan natrium $(\mathrm{Na})$ dalam larutan tanah $8 \%$ sampai dengan $15 \%$ selama lebih dari $>4$ bulan dalam setahun.

Pasang surut air laut berpengaruh terhadap proses pembentukan tanah di daerah pasang surut. Intensitas pengaruh pasang surut air laut terhadap pembentukan tanah di daerah pasang surut sangat ditentukan oleh jarak atau jauhnya dari pinggir sungai atau pinggir laut. Hasil penelitian Purwanto et al. (2002) menunjukkan bahwa jarak dari laut berpengaruh nyata terhadap konsentrasi kation $\mathrm{Mg}$ dalam larutan tanah maupun kation $\mathrm{Mg}$ terjerap yang dapat dipertukarkan, dimana konsentrasi Mg mengalami penurunan dengan semakin jauh jaraknya dari laut.

Variasi sifat tanah disamping terjadi menurut jarak dari pinggir sungai juga dapat terjadi menurut kedalaman lapisan tanah mengingat proses pembentukan tanah di daerah pasang surut tidak terlepas dari proses pengendapan yang terjadi secara simultan. Hasil penelitian sebelumnya pada ordo tanah Ultisol menunjukkan bahwa semakin ke arah dalam lapisan tanah dari permukaan tanah maka $\mathrm{pH}$ tanah semakin meningkat (kemasaman menurun); sebaliknya sifat kimia tanah lainnya seperti hidrogen dan alumunium dapat dipertukarkan, kation-kation basa dapat dipertukarkan $(\mathrm{Ca}, \mathrm{Mg}, \mathrm{K}$ dan $\mathrm{Na}$ ), kejenuhan basa (KB), kapasitas tukar kation (KTK), karbon organik, nitrogen total, fosfor tersedia dan $\mathrm{K}_{2} \mathrm{O}$ total mengalami penurunan (Basuki et al., 2014).

Untuk mengetahui seberapa besar pengaruh jarak lokasi dari pinggir sungai dan kedalaman lapisan tanah terhadap sifat tanah di daerah pasang surut maka akan dilakukan pengamatan sifat kimia dan kesuburan tanah, 
pada berbagai jarak dari pinggir sungai pada dua kedalaman lapisan tanah. Penelitian ini bertujuan untuk mengetahui pengaruh jarak lokasi dari pinggir sungai dan pengaruh kedalaman lapisan tanah terhadap sifat kimia tanah di lahan pasang surut.

\section{BAHAN DAN METODE}

Bahan-bahan yang digunakan dalam penelitian ini meliputi plastik sampel tanah, sampel tanah dan bahan kimia untuk analisis tanah di laboratorium. Alat-alat yang digunakan meliputi ayakan tanah $2 \mathrm{~mm}$, ring pengambilan sampel tanah mineral, meteran, pisau lapang, parang dan peralatan untuk keperluan analisis tanah di laboratorium.

Penelitian dilaksanakan dengan melakukan pengambilan 6 sampel tanah pada jalur transek tegak lurus arah sungai pada daerah pasang surut Desa Bajarum, Kecamatan Kota Besi Kabupaten Kotawaringin Timur, Provinsi Kalimantan Tengah. Jarak antar titik lokasi pengambilan sampel pada transek sejauh 250, 500, 750, 1.000, 1.250 dan 1.500 meter. Pengambilan sampel tanah pada masing-masing titik lokasi diambil pada dua kedalaman lapisan tanah, yaitu lapisan I $(0 \mathrm{~cm}-25 \mathrm{~cm})$ dan II $(25$ $\mathrm{cm}$ - $50 \mathrm{~cm}$ ) dari permukaan tanah. Pengambilan sampel pada masing-masing kedalaman lapisan tanah dilakukan dengan menggunakan alat bantu pipa stainless steel berdiameter $5,08 \mathrm{~cm}$. Sampel tanah untuk setiap lapisan kedalaman diambil secara proporsional dan komposit dari masingmasing lapisan tersebut selanjutnya diambil kurang lebih $1 \mathrm{~kg}$ untuk dikeringanginkan, diayak dengan ukuran lubang ayakan $2 \mathrm{~mm}$ dan dianalisis di laboratorium UPT. Laboratorium Dasar dan Analitik Universitas Palangka Raya.

Paramater sifat kimia tanah yang dianalisis di laboratorium dan metode analisisnya adalah sebagai berikut. Tingkat kemasaman tanah $\left(\mathrm{pH} \mathrm{H}_{2} \mathrm{O} \quad 1: 2,5\right)$ diukur dengan elektroda $\mathrm{pH}$-meter, kapasitas tukar kation (KTK) dan kejenuhan basa (KB) dianalisis dengan metode ekstraksi menggunakan NH4OAc I $\mathrm{N}$ pada $\mathrm{pH} 7,0$, kandungan karbon-organik (C-org) dianalisis dengan metode Kurmis (kolorimetri), kandungan $\mathrm{N}$ total dianalisis dengan metode Kjehdahl, kandungan $\mathrm{P}_{2} \mathrm{O}_{5}$ total dan $\mathrm{K}_{2} \mathrm{O}$ total dianalisis dengan metode ekstraksi $\mathrm{HCl} 25 \%$, alumunium dan hydrogen dapat dipertukarkan (Al-dd dan $\mathrm{H}$-dd) dianalisis dengan metode ekstraksi $\mathrm{KCl} 1 \mathrm{~N}$. Penilaian status kesuburan tanah didasarkan pada Term Of Reference Klasifikasi Kesesuaian Lahan P3MT (Staf Pusat Penelitian Tanah, 1983). Analisis data dilakukan dengan penghitungan nilai rata-rata untuk setiap variabel pengamatan, selanjutnya dibandingkan dengan kriteria penilaian sifat kimia tanah (Staf Pusat Penelitian Tanah, 1983).

\section{HASIL DAN PEMBAHASAN}

\section{Deskripsi Lahan di Lokasi Penelitian.}

Secara geografis lokasi penelitian terletak antara $112^{\circ} 7^{\prime} 29^{\prime \prime}-113^{\circ} 14^{\prime} 22^{\prime \prime}$ Bujur Timur dan $1^{\circ} 11^{\prime} 504^{\prime \prime}-3^{\circ} 18^{\prime} 51^{\prime \prime}$ Lintang Selatan, menurut Schmidth- Ferguson termasuk tipe iklim B (daerah basah dengan tipe vegetasi hutan hujan tropis). Lokasi penelitian merupakan lahan pasang surut air payau (pasang surut zona 1) dengan tipe luapan B dimana lahan hanya terluapi oleh air pasang besar. Tipologi lahan di wilayah studi merupakan lahan potensial, dimana tanahnya mempunyai lapisan sulfidik atau lapisan pirit dengan kadar $<2 \%$ dan lapisan tersebut berada pada kedalaman lebih dari $50 \mathrm{~cm}$ dari permukaan tanah. Jenis tanahnya adalah tanah alluvial atau setara dengan sulfaquent. Kedalaman air tanah pada wilayah penelitian mempunyai kisaran antara $25 \mathrm{~cm}$ hingga $50 \mathrm{~cm}$ dari permukaan tanah. Kedalaman lapisan pirit bervariasi antara $55-80 \mathrm{~cm}$ dari permukan tanah, semakin jauh jarak dari pinggir sungai kedalaman piritnya semakin meningkat.

\section{Hasil Analisis Sifat Kimia dan Kesuburan Tanah}

Hasil analisis sifat kimia tanah di laboratorium disajikan pada Tabel 1.

\section{Reaksi Tanah (pH Tanah)}

Reaksi tanah merupakan istilah untuk menyatakan tingkat kemasaman tanah $(\mathrm{pH})$ yaitu nilai logaritma negatif dari kandungan ion hidrogen dalam larutan tanah. Ion-ion hidrogen ini ada yang terdapat bebas dalam larutan tanah dan ada yang berada dalam bentuk terjerap pada permukaan koloid tanah. 
Tabel 1. Rata-rata Hasil Analisis Sifat Kimia Tanah Desa Bajarum, Kecamatan Kota Besi, Kabupaten Kotawaringin Timur, Provinsi Kalimantan Tengah.

\begin{tabular}{ccccccccccc}
\hline \multicolumn{2}{c}{ Sampel Tanah } & \multicolumn{7}{c}{ Parameter Sifat Kimia Tanah } \\
\hline $\begin{array}{c}\text { Jarak dari } \\
\text { Sungai }\end{array}$ & Lapisan & $\begin{array}{c}\mathrm{C}- \\
\text { organik } \\
(\%)\end{array}$ & $\begin{array}{c}\mathrm{N}-\text { total } \\
(\%)\end{array}$ & $\begin{array}{c}\mathrm{P}_{2} \mathrm{O}_{5} \\
(\mathrm{mg} / 100 \mathrm{~g})\end{array}$ & $\begin{array}{c}\mathrm{K}_{2} \mathrm{O} \\
(\mathrm{mg} / 100 \mathrm{~g})\end{array}$ & $\begin{array}{c}\mathrm{Al}-\mathrm{dd} \\
(\mathrm{cmol}(+) / \mathrm{kg})\end{array}$ & $\begin{array}{c}\mathrm{H}-\mathrm{dd} \\
(\mathrm{cmol}(+) / \mathrm{kg})\end{array}$ & $\mathrm{pH}$ & $\mathrm{KB}(\%)$ & $\begin{array}{c}\mathrm{KTK} \\
(\mathrm{cmol}(+) / \mathrm{kg})\end{array}$ \\
\hline \multirow{2}{*}{$250 \mathrm{~m}$} & I & 6,70 & 0,06 & 10,07 & 16,03 & 0,35 & 2,66 & 4,45 & 1,18 & 3,16 \\
& II & 6,09 & 0,03 & 8,05 & 10,06 & 0,30 & 2,08 & 4,48 & 2,14 & 2,57 \\
$500 \mathrm{~m}$ & I & 10,03 & 0,11 & 16,98 & 24,89 & 0,27 & 2,31 & 4,52 & 1,97 & 8,87 \\
& II & 9,13 & 0,09 & 13,00 & 19,76 & 0,23 & 1,87 & 4,59 & 3,02 & 7,44 \\
$750 \mathrm{~m}$ & I & 12,12 & 0,14 & 19,47 & 31,41 & 0,25 & 2,20 & 4,64 & 2,52 & 11,30 \\
& II & 11,35 & 0,13 & 18,60 & 26,07 & 0,22 & 1,62 & 4,67 & 8,14 & 10,20 \\
$1.000 \mathrm{~m}$ & I & 12,71 & 0,18 & 24,01 & 42,41 & 0,23 & 2,15 & 4,71 & 7,22 & 21,60 \\
& II & 11,97 & 0,16 & 21,14 & 40,63 & 0,21 & 1,53 & 4,76 & 11,97 & 12,47 \\
$1.250 \mathrm{~m}$ & I & 13,39 & 0,21 & 28,49 & 47,81 & 0,17 & 2,20 & 4,79 & 10,75 & 30,42 \\
& II & 12,07 & 0,20 & 25,95 & 44,60 & 0,16 & 1,29 & 4,84 & 13,40 & 23,49 \\
$1.500 \mathrm{~m}$ & I & 14,12 & 0,23 & 33,17 & 52,70 & 0,14 & 1,90 & 4,89 & 14,25 & 31,38 \\
& II & 13,00 & 0,22 & 29,08 & 49,56 & 0,12 & 1,24 & 4,93 & 19,74 & 31,16 \\
\hline
\end{tabular}

Karena itu penetapan $\mathrm{pH}$ tanah sering dilakukan dengan dua cara yaitu dengan pelarut air untuk mengukur ion-ion hidrogen bebas dan pelarut $\mathrm{KCl}$ untuk mengukur ion-ion hidrogen yang dapat dipertukarkan dan yang bebas dalam larutan tanah.

Reaksi tanah mempunyai implikasi terhadap komposisi dan ketersediaan unsur hara tanah serta kemungkinan munculnya senyawa racun. Hampir semua unsur hara ketersediaannya bagi tanaman dipengaruhi oleh reaksi tanah atau $\mathrm{pH}$ tanah. Secara umum tanahtanah dengan kondisi $\mathrm{pH}$ mendekati netral $(\mathrm{pH}$ 4,5 - 6,6) merupakan kondisi yang optimum untuk pertumbuhan tanaman. Pada kisaran $\mathrm{pH}$ ini unsur-unsur yang dibutuhkan tanaman berada dalam keadaan tersedia seperti $\mathrm{Ca}, \mathrm{Mg}$, $\mathrm{NH}_{4}{ }^{+}, \mathrm{HPO}_{4}{ }^{+}$dan unsur-unsur mikro.

Berdasarkan hasil analisis tanah di laboratorium sebagaimana disajikan pada Tabel 1 dapat dilihat bahwa tanah di lokasi penelitian tergolong masam dengan kisaran $\mathrm{pH}$ 4,45 - 4,93. Dalam kondisi tanah mineral yang masam ini ( $\mathrm{pH}$ rendah) unsur-unsur seperti besi, mangan dan aluminium kelarutannya meningkat sebagai ion-ion logam terhidrasi dalam larutan tanah sehingga dapat meracuni tanaman (Tan, 1982). Pada kondisi masam ini aluminium merupakan kation yang dominan pada permukaan koloid tanah, unsur ini mempengaruhi ketersediaan fosfat, dimana fosfat akan terikat oleh aluminium dan besi membentuk endapan yang tidak dapat diserap oleh tanaman. Disamping keracunan unsurunsur tersebut tanah mineral masam sering menjadi kurang subur karena kekurangan $\mathrm{Ca}$ dan $\mathrm{Mg}$ serta tingginya kejenuhan aluminium, oleh karena itu untuk mengatasi masalah kemasaman tersebut diantaranya dapat dilakukan dengan pengapuran baik dengan kapur kalsit $\left(\mathrm{CaCO}_{3}\right)$ maupun dolomit $(\mathrm{CaMg}$ $\left(\mathrm{CO}_{3}\right)_{2}$ untuk mengurangi pengaruh negatif unsur-unsur beracun tersebut dan untuk meningkatkan $\mathrm{pH}$ sehingga unsur-unsur hara menjadi tersedia (Hardjowigeno, 1992).

Secara umum dapat dilihat bahwa nilai $\mathrm{pH}$ tanah meningkat dengan semakin jauh jaraknya dari pinggir sungai Mentaya. Nilai $\mathrm{pH}$ lapisan atas $(0-25) \mathrm{cm}$ relatif lebih rendah dibanding nilai $\mathrm{pH}$ lapisan bawah $(25-50) \mathrm{cm}$. Pola perubahan $\mathrm{pH}$ tanah menurut jarak dari lokasi pinggir sungai dan kedalaman lapisan tanah sebagaimana disajikan pada Gambar 1.

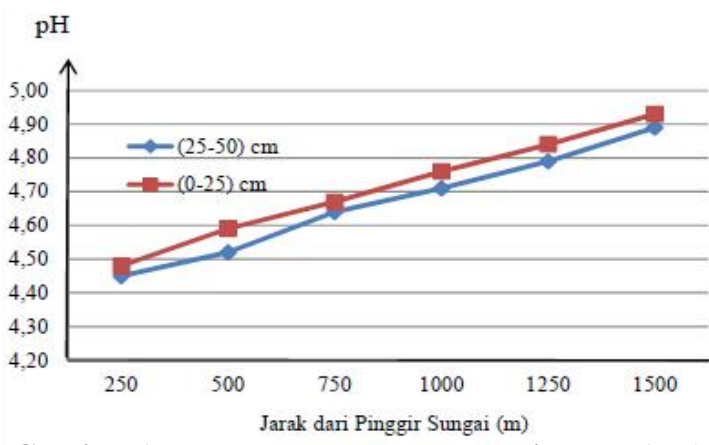

Gambar 1. Kemasaman Tanah (pH) berdasarkan Jarak dari Pinggir Sungai dan Kedalaman Lapisan Tanah

Nilai $\mathrm{pH}$ tanah meningkat dengan semakin jauh jaraknya dari pinggir sungai. Hal ini di sebabkan karena dengan semakin jauh 
jarak dari pinggir sungai kandungan alumunium dan hydrogen dapat dipertukarkan (Al-dd dan H-dd) tanah semakin menurun sebagaimana ditunjukkan pada data Tabel 1, Gambar 8 dan Gambar 9. Sebagaimana diketahui bahwa baik $\mathrm{H}$-dd maupun Al-dd merupakan sumber kemasaman di dalam tanah (Nyarko, 2012; Nweke and Nsoanya, 2013). Dengan semakin rendahnya kandungan Al-dd dan H-dd sebagai sumber kemasaman tanah maka nilai $\mathrm{pH}$ tanahnya akan semakin tinggi. Hasil penelitian Whitley et al. (2016) menunjukkan bahwa ada korelasi antara kadar Al-dd dengan $\mathrm{pH}$ tanah, semakin tinggi kadar Al-dd maka semakin rendah $\mathrm{pH}$ tanah, tanah dengan kadar Al-dd 20,0 mg/kg mempunyai pH 5,0; pada tingkat kadar Al-dd 10,0 mg/kg mempunyai $\mathrm{pH}$ 5,2 dan pada tingkat kadar Aldd 3,0 mg/kg mempunyai $\mathrm{pH}$ 5,8.

Secara umum nilai $\mathrm{pH}$ lapisan atas $(0$ $25) \mathrm{cm}$ relatif lebih rendah dibanding nilai $\mathrm{pH}$ lapisan bawah $(25-50) \mathrm{cm}$. Lebih rendahnya nilai $\mathrm{pH}$ tanah lapisan atas dibandingkan nilai pH tanah lapisan bawah disebabkan karena kandungan ion $\mathrm{H}+$ dan $\mathrm{Al} 3+$ pada tanah lapisan atas lebih tinggi dibandingkan kandungan ion $\mathrm{H}+$ dan $\mathrm{Al3}+$ pada tanah lapisan bawah (Tabel 1). Baik ion $\mathrm{H}+$ maupun ion Al3+ merupakan sumber kemasaman bagi tanah. Lebih tingginya kandungan ion $\mathrm{H}+$ dan $\mathrm{Al3}+$ pada tanah lapisan atas ini disebabkan karena tanah lapisan atas telah mengalami tingkat perkembangan yang lebih lanjut dibandingkan tanah lapisan bawah. Hal tersebut akan mengakibatkan tingkat pelapukan mineral berlangsung lebih intensif pada lapisan atas dan sebagai hasilnya akan dihasilkan $\mathrm{H}+$ dan Al3+yang lebih banyak pada lapisan atas, kedua ion sumber kemasaman ini merupakan hasil pelapukan atau hancuran dari mineral liat (Hardjowigeno, 1992). Tanah lapisan atas juga mengandung bahan organik lebih tinggi dibanding kandungan bahan organik tanah lapisan bawah. Asam-asam organik yang terbentuk selama proses dekomposisi bahan organik yang berlangsung kurang sempurna dalam kondisi lahan pasang surut ini juga menyumbangkan sumber kemasamaan yang lebih tinggi pada tanah lapisan atas.

Nilai $\mathrm{pH}$ tanah yang rendah mengindikasikan bahwa komplek jerapan tanah lebih didominasi oleh kation asam. Dalam kondisi tanah mineral yang masam ( $\mathrm{pH}$ rendah) unsur-unsur besi, mangan dan aluminium kelarutannya meningkat sebagai ion-ion logam terhidrasi dalam larutan tanah sehingga dapat meracuni tanaman (Tan, 1982). Pada kondisi $\mathrm{pH}$ ini aluminium merupakan kation yang dominan pada permukaan koloid tanah, unsur ini mempengaruhi ketersediaan fosfat, dimana fosfat akan terikat oleh aluminium dan besi membentuk endapan yang tidak dapat diserap oleh tanaman. Disamping keracunan unsurunsur tersebut tanah-tanah mineral masam sering menjadi kurang subur karena kekurangan $\mathrm{Ca}$ dan $\mathrm{Mg}$ serta tingginya kejenuhan aluminium. Oleh karena itu untuk mengatasi masalah kemasaman tersebut diantaranya dilakukan pengapuran baik dengan kapur kalsit $\left(\mathrm{CaCO}_{3}\right)$ maupun dolomit $\left(\mathrm{CaMg}\left(\mathrm{CO}_{3}\right)_{2}\right.$. untuk mengurangi pengaruh negatif unsur-unsur tersebut dan untuk meningkatkan $\mathrm{pH}$ sehingga unsur-unsur hara menjadi tersedia (Hardjowigeno, 1992).

\section{Kandungan Karbon-Organik (C-org)}

Bahan organik berasal dari hasil dekomposisi sisa-sisa jaringan tanaman dan binatang di dalam tanah. Kandungan bahan organik tanah ditentukan dengan cara mengukur kandungan karbon (C) organik pada tanah tersebut. Kandungan C-organik tanah cukup bervariasi dari rendah hingga tinggi. Adanya variasi kandungan C-organik dari rendah hingga tinggi ini antara lain disebabkan karena adanya perbedaan kondisi vegetasi yang dapat mempengaruhi tinggi rendahnya akumulasi bahan organik di permukaan tanah dan juga karena adanya perbedaan kondisi topografi yang dapat mempengaruhi intensitas proses oksidasi bahan organik di permukaan tanah.

Berdasarkan hasil analisis tanah di laboratorium sebagaimana disajikan pada Tabel 1 dapat dilihat bahwa C-organik di lokasi penelitian berkisar 6,09 - 14,12 \% (secara umum tergolong kategori sangat tinggi). Kandungan C-organik tanah meningkat dengan semakin jauh jaraknya dari pinggir sungai. Kandungan C-organik lapisan atas $(0$ - 25) cm lebih tinggi dibanding kandungan C-organik lapisan bawah (25 - 50) $\mathrm{cm}$. Pola perubahan $\mathrm{C}$ - organik tanah menurut jarak dari lokasi pinggir sungai dan kedalaman 
lapisan tanah sebagaimana disajikan pada Gambar 2.

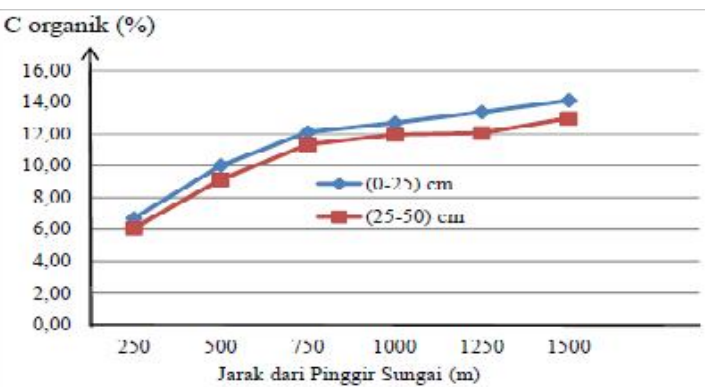

Gambar 2. Kandungan C-organik berdasarkan Jarak dari pinggir Sungai dan Kedalaman Lapisan Tanah

Bahan organik berasal dari hasil dekomposisi secara biologis sisa-sisa jaringan tanaman dan binatang di dalam tanah. Kandungan bahan organik tanah ditentukan dengan cara mengukur kandungan karbon (C) organik pada tanah tersebut. Kandungan Corganik tanah daerah penelitian cukup bervariasi dari tinggi hingga rendah yaitu berkisar antara 14,12 - 6,09\%. Adanya variasi kandungan C-organik dari rendah hingga tinggi ini antara lain disebabkan karena adanya perbedaan kondisi vegetasi yang dapat mempengaruhi tinggi rendahnya akumulasi bahan organik di permukaan tanah dan juga karena adanya perbedaan kondisi topografi / elevasi lahan yang dapat mempengaruhi intensitas proses oksidasi bahan organik.

Kandungan $\mathrm{C}$ organik tanah meningkat dengan semakin jauh jaraknya dari pinggir sungai. Meningkatnya kandungan $\mathrm{C}$ organik dengan semakin jauhnya jarak dari pinggir sungai disebabkan karena semakin kearah pinggir sungai pengaruh pengendapan akibat luapan air sungai semakin nyata. Proses pengendapan yang terus terjadi setiap terjadinya luapan air sungai ini mengakibatkan tanah yang berkembang pada daerah pinggiran sungai tersebut adalah tanah aluvial. Semakin jauh jarak dari pinggir sungai intensitas pengendapannya semakin berkurang yang mengakibatkan porsi bahan pembentuk tanah yang berasal dari bahan sedimen semakin berkurang, sebaliknya bahan penyusun tanah yang berasal dari sisa-sisa bahan organik semakin tinggi. Keadaan ini akan menyebabkan kandungan bahan organik tanahnya menjadi semakin tinggi dengan semakin jauhnya jarak dari pinggir sungai.

Kandungan C-organik pada lapisan atas $(0$ - 25) $\mathrm{cm}$ lebih tinggi dibandingkan kandungan C-organik pada lapisan bawah (25 50) $\mathrm{cm}$. Lebih tingginya kandungan Corganik lapisan atas dibandingkan lapisan bawah disebakan karena sumber utama bahan organik tanah adalah sisa-sisa serasah yang berasal dari sisa tanaman dan juga hewan. Serasah-serasah tersebut paling banyak akan ditemukan dipermukaan tanah yang kemudian akan mengalami proses dekomposisi membentuk humus serta bercampur dengan tanah pada lapisan teratas, karena alasan proses tersebut maka dapat dipahami bila kandungan $\mathrm{C}$ - organik pada lapisan atas lebih tinggi dibandingkan kandungan C-organik pada lapisan bawah.

Variasi kandungan C-organik di dalam tanah dapat berpengaruh pada pertumbuhan tanaman di atasnya melalui pengaruhnya terhadap sifat fisik, kimia dan biologi tanah. Fungsi fisik bahan organik antara lain dapat merangsang terbentuknya struktur tanah yang baik, memperbaiki stabilitas agregat, porositas, aerasi, retensi air, menurunkan erodibilitas tanah dan mempengaruhi bobot isi dan warna tanah (Stevenson, 1982 dan Murphy, 2015). Secara kimia bahan organik menentukan jumlah muatan negatif tanah, KTK, pH tanah, sebagai agen pengkhelat serta mempunyai fungsi nutrisional dimana bahan organik berperan sebagai penyangga penyediaan $\mathrm{N}, \mathrm{P}$ dan $\mathrm{S}$ dan unsur-unsur mikro melalui proses mineralisasi serta sebagai penjerap kation $\mathrm{Ca}$, $\mathrm{Mg}, \mathrm{K}$ dan $\mathrm{Na}$ (Angelova et al., 2013 dan Audu, et al., 2013). Murphy (2015) juga mempertegas bahwa bahan organik tanah berperan dalam siklus hara, kapasitas tukar kation, kemasaman tanah, kapasitas menyangga (buffer), salinitas dan mempunyai kemampuan membentuk kompleks ligand. Sedangkan secara biologis bahan organik berperan sebagai sumber karbon dan sumber energi bagi aktivitas sebagian besar mikroorganisme di dalam tanah.

\section{Kandungan N Total, $\mathrm{P}_{2} \mathrm{O}_{5}$ Total dan $\mathrm{K}_{2} \mathrm{O}$ Total}

Berdasarkan hasil analisis tanah di laboratorium sebagaimana disajikan pada 
Tabel 1 dapat dilihat bahwa $\mathrm{N}$ total di lokasi penelitian tergolong rendah hingga sedang dengan kisaran 0,03 - 0,23\%. Kandungan $\mathrm{P}_{2} \mathrm{O} 5$ total tergolong rendah hingga sedang dengan kisaran 8,05 - 33,17 mg/100g. Kandungan $\mathrm{K}_{2} \mathrm{O}$ total tergolong rendah hingga tinggi dengan kisaran 10,06 - 52,70 mg/100g.

Kandungan $\mathrm{N}$ total, $\mathrm{P}_{2} \mathrm{O}_{5}$ total dan $\mathrm{K}_{2} \mathrm{O}$ total tanah meningkat dengan semakin jauh jaraknya dari pinggir sungai. Kandungan $\mathrm{N}$ total, $\mathrm{P}_{2} \mathrm{O}_{5}$ total dan $\mathrm{K}_{2} \mathrm{O}$ total tanah lapisan atas $(0-25) \mathrm{cm}$ lebih tinggi dibanding tanah lapisan bawah $(25-50) \mathrm{cm}$. Pola perubahan $\mathrm{N}$ total, $\mathrm{P}_{2} \mathrm{O}_{5}$ total dan $\mathrm{K}_{2} \mathrm{O}$ total tanah menurut jarak dari lokasi pinggir sungai dan kedalaman lapisan tanah masing-masing disajikan pada Gambar 3, 4 dan 5.

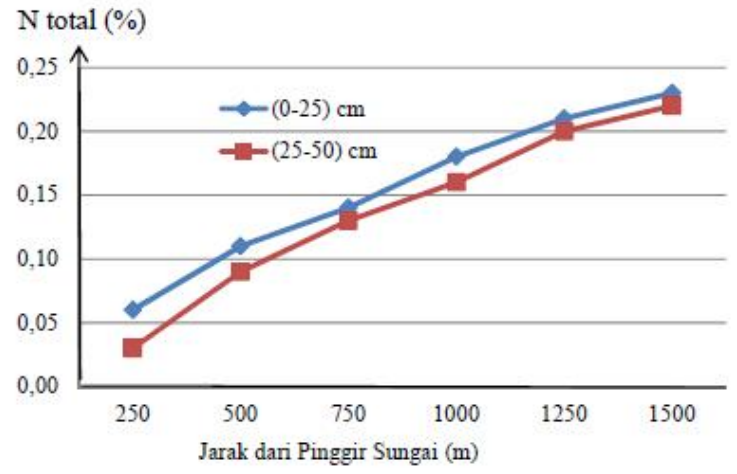

Gambar 3. Kandungan N Total berdasarkan Jarak dari Pinggir Sungai dan Kedalaman Lapisan Tanah

Dari hasil analisis laboratorium diketahui bahwa kandungan $\mathrm{N}$ total tanah tergolong rendah hingga sedang dengan kisaran $0,03-0,23 \%$. Sebagian besar persenyawaan nitrogen dalam tanah berada dalam bentuk organik dan hanya sedikit sekali dijumpai dalam bentuk anorganik, bentuk-bentuk $\mathrm{N}$ anorganik yang umum dijumpai dalam tanah adalah $\mathrm{NH}_{4}^{+}, \mathrm{NO}_{2}^{-}, \mathrm{NO}_{3}^{-}, \mathrm{N}_{2} \mathrm{O}$ dan $\mathrm{NO}$. Beberapa sumber $\mathrm{N}$ tanah antara lain dari dekomposisi nitrogen organik seperti protein dan asam amino yang ditemukan dalam bahan organik, penambatan biologis (simbiotik dan non simbiotik), pengendapan dari atmosfir, pengendapan sedimen erosi dan pemupukan (Rezig, Elhadi and Mubarak, 2012). Bahan organik tanah berasal dari sisa tanaman dan hewan yang umumnya menumpuk di permukaan tanah. Nitrogen tanah juga dapat berasal dari input pemupukan, namun untuk di wilayah lokasi penelitian ini bukan merupakan lahan budidaya intensif dimana tidak ada kegiatan pemupukan yang dilakukan oleh pemilik lahannya.

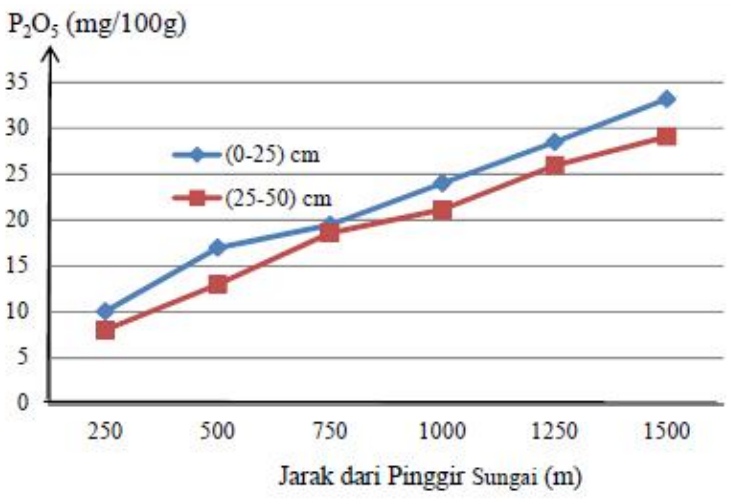

Gambar 4. $\mathrm{P}_{2} \mathrm{O}_{5}$ Total berdasarkan Jarak dari Pinggir Sungai dan Kedalaman Lapisan Tanah

Dari hasil analisis laboratorium diketahui bahwa kandungan $\mathrm{P}_{2} \mathrm{O}_{5}$ total di lokasi penelitian secara umum tergolong rendah hingga sedang dengan kisaran 8,05 - 33,17 $\mathrm{mg} / 100 \mathrm{~g}$. Penilaian kandungan fosfor total biasanya dinyatakan dalam bentuk $\mathrm{P}_{2} \mathrm{O}_{5}$ dalam ekstrak $\mathrm{HCl} 25 \%$, sedangkan fosfor tersedia dalam bentuk $\mathrm{P}_{2} \mathrm{O}_{5}$ dalam ekstrak Bray I. Sumber $\mathrm{P}_{2} \mathrm{O}_{5}$ tanah dapat berasal dari hasil perombakan bahan organik, pelapukan batuan dan mineral yang mengandung fosfor, pengendapan sedimen erosi dan kegiatan pemupukan.

Fosfor (P) di dalam tanah dijumpai dalam dua bentuk, yaitu $\mathrm{P}$ organik dan $\mathrm{P}$ anorganik. Kedua bentuk senyawa fosfor ini pada akhirnya dapat dimanfaatkan tanaman. Senyawa P-organik berasal dari sisa tanaman, hewan dan jazad renik. Bentuk P-organik tanah terdapat sebagai senyawa ester dari senyawa seperti inositol, fosfolipida dan asam nukleat. Bentuk $P$ anorganik biasanya dibagi dalam tiga bentuk aktif dan dua bentuk dalam bentuk yang relatif tidak aktif, bentuk-bentuk yang aktif dapat dikelompokkan menjadi fosfat yang terikat kalsium (Ca-P), fosfat yang terikat aluminium (Al-P) dan fosfat yang terikat besi (Fe-P). Sedangkan yang relatif tidak aktif terdiri dari P-occluded dan dalam bentuk reduktan 
terlarut (yang dapat larut sebagian atau seluruhnya dalam keadaan tereduksi). Bentuk-bentuk anorganik fosfor dalam tanah tergantung pada tingkat pelapukan kimia tanah. Pada tanah-tanah yang mengalami pelapukan lanjut sebagian besar fosfor berada dalam bentuk yang relatif tidak aktif karena terbentuknya selaput besi dan aluminium oksida (Hardjowigeno, 1992).

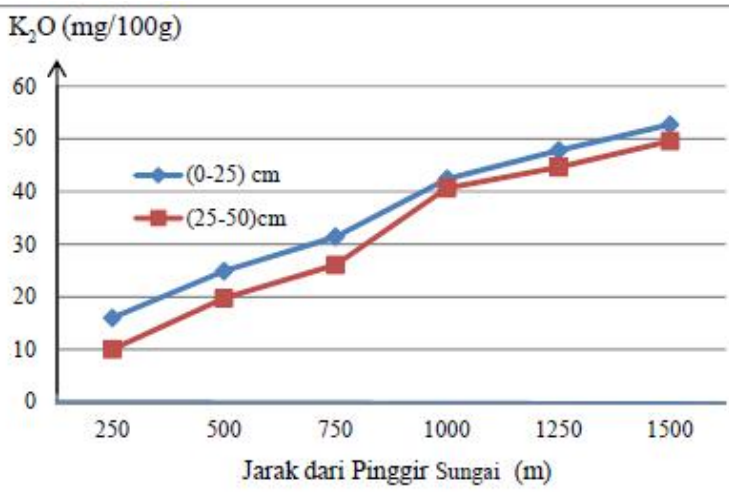

Gambar 5. $\mathrm{K}_{2} \mathrm{O}$ Total berdasarkan Jarak dari Pinggir Sungai dan Kedalaman Lapisan Tanah

Dari hasil analisis laboratorium diketahui bahwa kandungan $\mathrm{K}_{2} \mathrm{O}$ total di lokasi penelitian tergolong rendah hingga tinggi yaitu berkisar antara 10,06 - 52,70 mg/100g. Kadar kalium yang ditetapkan dengan pengekstrak $\mathrm{HCl} 25 \%$ dianggap sebagai jumlah kalium potensial dalam bentuk $\mathrm{K}_{2} \mathrm{O}$. Sedangkan kalium yang diekstrak dengan $\mathrm{NH}_{4} \mathrm{OAc}$ I $\mathrm{N}$ pada $\mathrm{pH}$ 7,0 dianggap sebagai jumlah kalium tersedia dalam bentuk ion $\mathrm{K}^{+}$. Sumber $\mathrm{K}_{2} \mathrm{O}$ tanah dapat berasal dari hasil perombakan bahan organik, pelapukan batuan dan mineral yang mengandung kalium (seperti muskovit, biotit, ortoklas dan mikroklin), pengendapan sedimen erosi dan kegiatan pemupukan.

Kalium (K) di dalam tanah dapat berada dalam bentuk kalium dapat dipertukarkan (K-dd) yang teradsorpsi permukaan koloid, dalam keadaan terlarut dalam larutan tanah, terikat oleh mineral liat seperti illit, kalium yang merupakan bagian dari mineral-mineral kristal seperti pada mika dan felsdfar serta kalium dalam jazad organik. Kalium tanah juga dapat digolongkan dalam bentuk yang relatif tidak tersedia yaitu mineral feldspar dan mika, segera tersedia yaitu kalium dapat dipertukarkan dan kalium dalam larutan tanah, dan lambat tersedia yaitu kalium tidak dapat ditukar.

Nilai $\mathrm{N}$ total, $\mathrm{P}_{2} \mathrm{O}_{5}$ total dan $\mathrm{K}_{2} \mathrm{O}$ total tanah meningkat dengan semakin jauh jaraknya dari pinggir sungai. Meningkatnya nilai $\mathrm{N}$ total, $\mathrm{P}$ total dan $\mathrm{K}$ total tanah dengan semakin jauhnya jarak dari pinggir sungai disebabkan karena meningkatnya kandungan C-organik tanah seiring dengan semakin jauhnya jarak dari pinggir sungai (Gambar 4). Hasil dekomposisi bahan organik akan menghasilkan berbagai jenis unsur hara seperti nitrogen, fosfor, kalium, sulfur dan unsur hara lainnya termasuk unsur hara mikro (Stevenson, 1982 dan Murphy, 2015).

Nilai $\mathrm{N}$ total, $\mathrm{P}_{2} \mathrm{O}_{5}$ total dan $\mathrm{K}_{2} \mathrm{O}$ total tanah pada lapisan atas $(0-25) \mathrm{cm}$ lebih tinggi dibandingkan nilai $\mathrm{N}$ total, $\mathrm{P}_{2} \mathrm{O}_{5}$ total dan $\mathrm{K}_{2} \mathrm{O}$ total tanah pada lapisan bawah $(25-50)$ $\mathrm{cm}$. Hal ini disebakan karena salah satu sumber nitrogen $(\mathrm{N})$, fosfor $(\mathrm{P})$ dan kalium $(\mathrm{K})$ tanah adalah berasal dari dekomposisi bahan organik. Mengingat bahwa sumber utama bahan organik adalah dari sisa vegetasi yang terakumulasi dipermukaan tanah maka hasil dekomposisi bahan organik ini juga akan terakumulasi pada tanah lapisan atas. Sebagaimana diketahui bahwa bentuk- bentuk N-organik dapat berupa senyawa protein dan asam-asam amino, sedangkan bentuk-bentuk senyawa $\mathrm{P}$ organik tanah dapat berupa asam nukleat, fosfolifid dan inositolfosfat. Senyawa-senyawa organik tersebutkan mengalami humifikasi sejalan dengan berlangsungnya proses dekomposisi bahan organik tanah sehingga pada akhirnya akan dapat meningkatkan kandungan Nitrogen $(\mathrm{N})$ dan Fosfor $(\mathrm{P})$ total dalam tanah. Hal yang serupa juga terjadi pada senyawa- senyawa organik yang mengandung kalium setelah terdekomposisi juga akan meningkatkan kandungan kalium $\left(\mathrm{K}_{2} \mathrm{O}\right)$ total di dalam tanah. Mengingat bahwa sumber utama bahan organik adalah dari sisa vegetasi yang terakumulasi di permukaan tanah maka hasil dekomposisinya akan lebih banyak meningkatkan kandungan $\mathrm{N}$ total, $\mathrm{P}_{2} \mathrm{O}_{5}$ total dan $\mathrm{K}_{2} \mathrm{O}$ total tanah pada lapisan atas dibandingkan lapisan bawah (Rezig, Elhadi and Mubarak, 2012). 


\section{Kapasitas Tukar Kation (KTK)}

Kapasitas tukas kation (KTK) merupakan kemampuan suatu tanah untuk mengadsorpsi dan mempertukarkan kation pada kompleks jerapan tanah dengan kation pada larutan tanah yang dinyatakan dalam satuan $\mathrm{cmol}(+) / \mathrm{kg}$ tanah. Karena kation pada komplek jerapan tanah diadsorbsi oleh muatan negatif koloid tanah maka KTK juga merupakan gambaran tentang jumlah total muatan negatif pada tanah tersebut. Nilai KTK dapat digunakan sebagai indikator dalam memprediksi tingkat kesuburan tanah dan sebagai dasar dalam memberikan tindakan pengelolaan secara potensial untuk mempertahankan dan meningkatkan tingkat kesuburan tanah. Tanah yang baik dan subur adalah tanah yang mempunyai KTK tinggi dan kejenuhan basa (KB) tinggi.

Berdasarkan hasil analisis tanah di laboratorium sebagaimana disajikan pada Tabel 1 dapat dilihat bahwa KTK di lokasi penelitian tergolong sangat rendah hingga tinggi dengan kisaran 2,57 - 31,16 cmol(+)/kg. Nilai KTK tanah meningkat dengan semakin jauh jaraknya dari pinggir sungai. Nilai KTK lapisan atas $(0-25) \mathrm{cm}$ lebih tinggi dibanding nilai KTK lapisan bawah $(25-50) \mathrm{cm}$. Pola perubahan nilai KTK tanah menurut jarak dari lokasi pinggir sungai dan kedalaman lapisan tanah sebagaimana disajikan pada Gambar 6 .

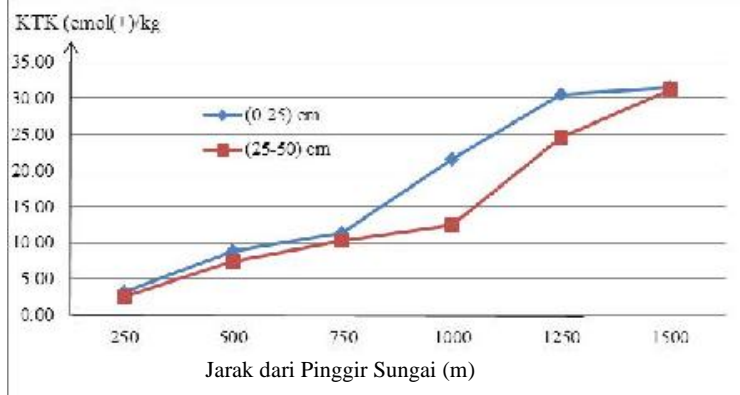

Gambar 6. Kapasitas Tukar Kation (KTK) berdasarkan Jarak dari Pinggir Sungai dan Kedalaman Lapisan Tanah

Nilai KTK tanah meningkat dengan semakin jauh jaraknya dari pinggir sungai, hal ini disebabkan karena dengan semakin jauh jarak dari pinggir sungai kandungan C-organik tanah dan nilai $\mathrm{pH}$ tanahnya semakin meningkat sebagaimana ditunjukkan pada
Gambar 4, Gambar 10 dan data pada Tabel 1. Dengan semakin tingginnya kandungan bahan organik atau C-organik tanah maka berarti bahwa kandungan koloid organik tanah semakin tinggi. Koloid organik ini merupakan sumber muatan negatif terutama yang berasal dari disosiasi ion $\mathrm{H}^{+}$dari gugus fenol (-OH) dan gugus karboksil (-COOH). Dengan semakin meningkatnya jumlah muatan negatif tanah seiring dengan meningkatnya kandungan bahan organik tanah tersebut pada gilirannya akan meningkatkan jumlah kation terjerap pada koloid tanah sehingga nilai KTK tanahnya akan semakin tinggi. Muatan negatif yang bersumber dari koloid organik merupakan muatan negatif yang bergantung $\mathrm{pH}$, dimana semakin tinggi $\mathrm{pH}$ (semakin meningkatnya konsentrasi ion $\mathrm{OH}^{-}$dalam larutan tanah) maka jumlah muatan negatifnya akan semakin tinggi. Oleh sebab itu dengan semakin meningkatnya $\mathrm{pH}$ seiring dengan semakin jauh jaraknya dari pinggir sungai akan meningkatkan jumlah muatan negatif tanah yang pada gilirannya akan semakin meningkatkan KTK tanahnya (Hardjowigeno, 1992 dan Tan, 1982).

Secara umum kondisi tanah dengan KTK yang sangat rendah atau rendah sebagaimana ditemukan pada titik transek pengambilan sampel pada jarak $250 \mathrm{~m}, 500 \mathrm{~m}$ dan $750 \mathrm{~m}$ dari pinggir sungai ini kurang menguntungkan bagi pertumbuhan tanaman. Dengan KTK yang sangat rendah atau rendah berarti jumlah kation yang terjerap pada permukaan koloid baik koloid anorganik (liat) maupun koloid organik (humus) jumlahnya relatif rendah, termasuk kation-kation basa $(\mathrm{Ca}, \mathrm{Mg}, \mathrm{K}$ dan $\mathrm{Na}$ ) yang merupakan unsur hara tanaman. Semakin tinggi nilai KTK sebagaimana ditemukan pada titik transek pengambilan sampel pada jarak $1.000 \mathrm{~m}, 1.250$ $\mathrm{m}$ dan $1.500 \mathrm{~m}$ dari pinggir sungai maka jumlah kation yang terjerapnya semakin tinggi sehingga peluang tanaman untuk dapat menyerap unsur hara dari kation-kation basa $(\mathrm{Ca}, \mathrm{Mg}, \mathrm{K}$ dan $\mathrm{Na}$ ) semakin tinggi.

Nilai KTK pada lapisan atas (0 - 25) $\mathrm{cm}$ lebih tinggi dibandingkan nilai KTK pada lapisan bawah $(25-50) \mathrm{cm}$, hal ini disebakan karena lebih tingginya kandungan bahan organik tanah pada lapisan atas. Dengan 
semakin tingginya kandungan bahan organik suatu tanah maka akan semakin tinggi jumlah muatan negatif tanah khususnya yang berasal dari disosiasi ion $\mathrm{H}^{+}$dari gugus karboksilat $(-\mathrm{COOH})$ dan gugus hidroksil atau fenol $(-\mathrm{OH})$. Lebih tingginya jumlah muatan negatif dari koloid organik ini akan mengakibatkan nilai kapasitas tukar kation (KTK) tanah menjadi semakin tinggi (Hardjowigeno, 1992; Tisdale et al., 1999 dan Syekhfani, 2010).

\section{Kejenuhan Basa (KB)}

Kation-kation yang terjerap pada permukaan koloid tanah baik koloid anorganik (liat) maupun koloid organik (humus) dapat dikelompokan menjadi kation basa (K, $\mathrm{Ca}, \mathrm{Mg}$ dan $\mathrm{Na}$ ) dan kation asam (Al dan $\mathrm{H}$ ). Kation-kation tersebut teradsorbsi atau terjerap pada permukaan koloid tanah, namun dapat dipertukarkan kembali ke dalam larutan tanah membentuk suatu sistem keseimbangan dengan kation larutan tanah. Makin tinggi nilai kation tertukar suatu unsur, maka semakin besar pula potensi ketersediaan kation unsur tersebut untuk memenuhi keperluan tanaman, secara total jumlah kation basa yang menduduki kompleks adsorbsi tanah ini tercermin dari nilai kejenuhan basa. Kejenuhan basa (KB) menunjukkan jumlah relatif kation-kation basa yang menduduki komplek jerapan tanah. Kejenuhan basa dapat ditentukan dengan menjumlahkan seluruh kation-kation basa ( $\mathrm{K}, \mathrm{Ca}, \mathrm{Mg}$ dan $\mathrm{Na}$ ) dibagi dengan jumlah seluruh kation termasuk kation asam $(\mathrm{H}$ dan $\mathrm{Al})$ dan dinyatakan dalam \% (persen) Dengan demikian parameter ini memberikan gambaran ketersediaan kationkation tersebut yang diperlukan tanaman (Hardjowigeno, 1992).

Berdasarkan hasil analisis tanah di laboratorium sebagaimana disajikan pada Tabel 1 dapat dilihat bahwa kejenuhan basa di lokasi penelitian tergolong rendah dengan kisaran antara 1,18 - 19,74\%. Secara umum kondisi tanah dengan nilai kejenuhan basa (KB) yang rendah di lokasi penelitian ini kurang menguntungkan bagi pertumbuhan tanaman karena pada tanah dengan KB rendah berarti porsi kation basa terhadap total kation secara keseluruhan relatif rendah sebaliknya kation-kation asam terutama $\mathrm{H}$ dan $\mathrm{Al}$ lebih dominan. Kondisi tanah yang demikian ini akan sangat merugikan bagi pertumbuhan tanaman, untuk mengatasi kendala ini perlu dilakukan peningkatan nilai kejenuhan basa tanah dengan meningkatkan jumlah basa-basa misalnya dengan pemberian kapur dolomit.

Nilai KB tanah meningkat dengan semakin jauh jaraknya dari pinggir sungai. Nilai KB lapisan atas $(0-25) \mathrm{cm}$ relatif lebih rendah dibanding nilai $\mathrm{KB}$ lapisan bawah (25 50) $\mathrm{cm}$. Pola perubahan KB tanah menurut jarak dari lokasi pinggir sungai dan kedalaman lapisan tanah sebagaimana disajikan pada Gambar 7.

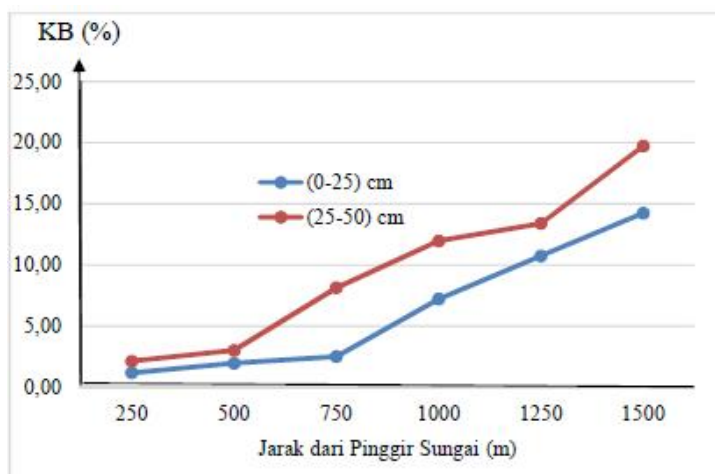

Gambar 7. Kejenuhan Basa (KB) berdasarkan Jarak dari Pinggir Sungai dan Kedalaman Lapisan Tanah

Nilai kejenuhan basa (KB) tanah meningkat dengan semakin jauh jaraknya dari pinggir sunga, hal ini disebabkan karena dengan semakin jauh jarak dari pinggir sungai kandungan alumunium dan hydrogen dapat dipertukarkan (Al-dd dan H-dd) tanah semakin menurun sebagaimana ditunjukkan pada Gambar 8, Gambar 9 dan Tabel 1. Dengan semakin rendahnya kandungan Al-dd dan H-dd tanah maka berarti secara relatif persentase kation basa terhadap total kation meningkat atau dengan kata lain nilai $\mathrm{KB}$ tanah akan semakin meningkat. Meningkatnya KB dengan semakin jauhnya jarak dari pinggir sungai juga seiring dengan peningkatan nilai $\mathrm{pH}$ tanah. Pada umumnya semakin tinggi $\mathrm{pH}$ tanah juga akan semakin tinggi $\mathrm{KB}$ tanahnya yang menandakan dominansi kation-kation basa dibanding kation asamnya (Hardjowigeno, 1992). 
Nilai KB lapisan atas $(0-25) \mathrm{cm}$ relatif lebih rendah dibanding nilai KB lapisan bawah $(25-50) \mathrm{cm}$. Lebih rendahnya nilai kejenuhan basa (KB) lapisan atas dibandingkan lapisan bawah disebakan karena kandungan $\mathrm{H}$-dd dan $\mathrm{Al}$-dd tanah lapisan atas lebih tinggi dibandingkan lapisan bawah (Tabel 1). Hal ini berarti bahwa porsi kation asam $\left(\mathrm{H}^{+}\right.$dan $\left.\mathrm{Al}^{3+}\right)$ tanah lapisan atas lebih banyak dibandingkan tanah lapisan bawah, yang berarti bahwa nilai kejenuhan basa tanah lapisan atas lebih rendah dibandingkan tanah lapisan bawah. Keadaan ini juga sejalan dengan nilai $\mathrm{pH}$ tanah lapisan atas yang lebih rendah dibandingkan $\mathrm{pH}$ tanah lapisan bawah. Biasanya nilai $\mathrm{KB}$ suatu tanah akan berbanding lurus dengan nilai $\mathrm{pH}$ tanah atau semakin tinggi $\mathrm{pH}$ tanah akan semakin tinggi nilai KB nya (Nduwumuremyi et al., 2013).

\section{Aluminium dan Hidrogen Dapat Dipertukarkan (Al-dd dan H-dd)}

Berdasarkan hasil analisis tanah di laboratorium sebagaimana disajikan pada Tabel 1 dapat diketahui bahwa kadar Al-dd di lokasi studi berkisar antara 0,12 - 0,35 cmol(+)/kg, sedangkan kadar $\mathrm{H}$-dd berkisar antara 1,24 - 2,66 cmol(+)/kg. Kandungan Aldd dan $\mathrm{H}$-dd secara umum menurun dengan semakin jauh jarak dari pinggir sungai. Hasil penelitian serupa yang dilakukan Purwanto $e t$ al. (2002) menunjukkan bahwa jarak dari laut tidak berpengaruh nyata terhadap konsentrasi kation dalam larutan tanah maupun kation terjerap yang dapat dipertukarkan, kecuali untuk Mg yang mengalami penurunan dengan semakin jauh jaraknya dari laut.

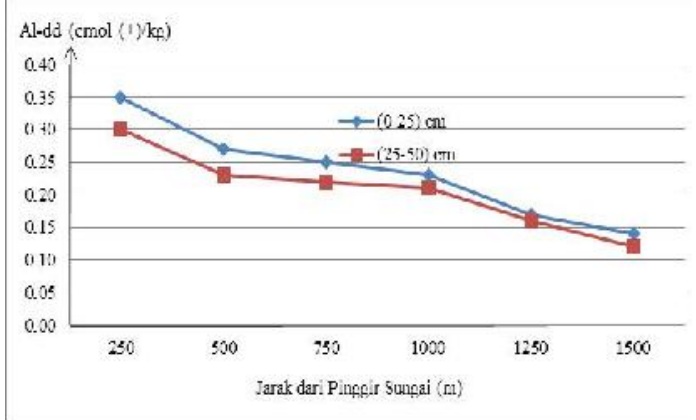

Gambar 8. Aluminium Dapat Dipertukarkan (Al-dd) berdasarkan Jarak dari Pinggir Sungai dan Kedalaman Lapisan Tanah.
Kandungan Al-dd dan H-dd pada lapisan atas $(0 \quad-25) \quad \mathrm{cm}$ lebih tinggi dibandingkan kandungan Al-dd dan H-dd pada lapisan bawah $(25-50) \mathrm{cm}$. Pola perubahan Al-dd dan H-dd tanah menurut jarak dari lokasi pinggir sungai dan kedalaman lapisan tanah masing-masing disajikan pada Gambar 8 dan 9 .

Rendahnya kandungan Al-dd di lokasi penelitian ini disebabkan karena tanah di lokasi studi mempunyai kandungan karbon (C) organik yang tergolong tinggi yaitu berkisar antara 6,09 - 14,12 \%. Dengan semakin tingginya kandungan bahan organik tanah ini berarti semakin kecil porsi fase padatan tanah yang terisi oleh bahan mineral tanah. Sumber alumunium dalam tanah adalah berasal dari hancuran bahan mineral tanah khususnya dari struktur mineral alumunium silikatnya (Hardjowigeno, 1993). Dengan semakin rendahnya porsi bahan mineral tanah maka akan semakin rendah kandungan alumunium di dalam tanah.

Kandungan Al-dd dan H-dd yang rendah sangat baik bagi kondisi pertumbuhan tanaman karena dapat menghindari kemungkinan terjadinya keracunan bagi tanaman. Rendahnya Al-dd juga akan mempermudah proses penyusunan enzim seperti sitokrom, katalase dan feroksidase.

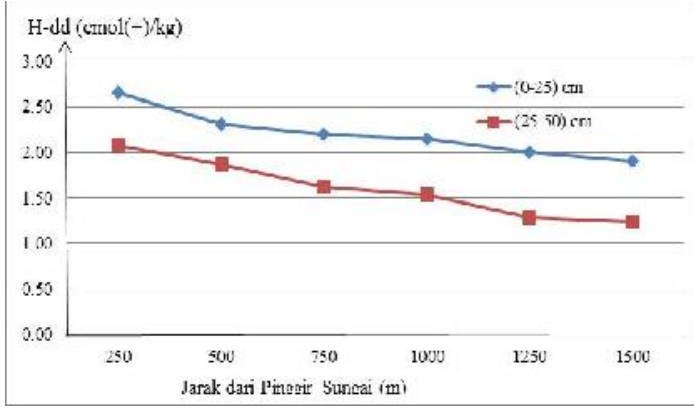

Gambar 9. Kandungan Hidrogen Dapat Dipertukarkan (H-dd) berdasarkan Jarak dari Pinggir Sungai dan Kedalaman Lapisan Tanah

Kandungan alumunium dan hydrogen dapat dipertukarkan (Al-dd dan H-dd) secara umum menurun dengan semakin jauh jarak dari pinggir sungai Mentaya, hal ini mungkin disebabkan karena semakin menurunnya dominansi bahan mineral tanah karena semakin meningkatnya kandungan C-organik tanah seiring dengan semakin jauhnya jarak dari 
pinggir sungai (Gambar 4). Sebagaimana diketahui bahwa sumber alumunium dalam tanah adalah berasal dari hancuran bahan mineral tanahnya.

Kandungan Al-dd dan $\mathrm{H}$-dd pada tanah lapisan atas $(0-25) \mathrm{cm}$ lebih tinggi dibandingkan kandungan Al-dd dan $\mathrm{H}$-dd pada tanah lapisan bawah $(25$ - 50) $\mathrm{cm}$, hal ini mungkin ada hubungannya dengan perbedaan tingkat perkembangan tanah pada kedua lapisan tersebut. Ditinjau dari tingkat perkembangan atau pelapukan tanah yang berasal dari batuan induk maka lapisan tanah yang telah mengalami pelapukan lebih lanjut adalah tanah pada lapisan atas disusul dengan tanah lapisan bawah. Semakin lanjut tingkat pelapukan tanah maka akan semakin banyak dibebaskan kation-kation yang berasal dari mineral liat terutama $\mathrm{H}^{+}$dan $\mathrm{Al}^{3+}$ yang berasal dari rusaknya struktur alumunium oktahedral (Hardjowigeno, 1993). dimana tanah lapisan atas merupakan lapisan yang telah mengalami pelapukan lebih lanjut sehingga sesuai dengan tingkat pelapukannya akan menghasilkan kation $\mathrm{H}^{+}$dan $\mathrm{Al}^{3+}$ lebih tinggi dibanding dengan tanah lapisan bawah.

\section{Status Kesuburan Tanah}

Kesuburan tanah merupakan gambaran tentang status ketersediaan unsur hara dalam tanah secara berimbang untuk memenuhi kebutuhan tanaman, dengan memperhatikan kemungkinan adanya senyawa-senyawa yang bersifat racun. Penilaian kesuburan tanah didasarkan pada Term Of Reference Klasifikasi Kesesuaian Lahan P3MT (Staf Pusat Penelitian Tanah, 1983). Aspek-aspek kimia tanah yang dijadikan parameter penilaian meliputi nilai kapasitas tukar kation (KTK), kejenuhan basa $(\mathrm{KB}), \mathrm{P}_{2} \mathrm{O}_{5}$ total, $\mathrm{K}_{2} \mathrm{O}$ total dan C-organik. Untuk keperluan penetapan status kesuburan tanah ini nilai parameter hasil analisis sifat kimia tanah yang digunakan adalah nilai parameter sifat kimia tanah lapisan atas pada $(0-25) \mathrm{cm}$. Tabel 2 menyajikan hasil penetapan status masing-masing parameter kesuburan tanah dan hasil penetapan status kesuburan tanah di wilayah studi.

Dari Tabel 2 dapat dilihat bahwa status kesuburan tanah pada titik pengamatan jarak $250 \mathrm{~m}$ dari pinggir sungai tergolong sangat rendah dengan faktor pembatas berupa rendahnya $\mathrm{KB}, \mathrm{P}_{2} \mathrm{O} 5$ total dan $\mathrm{K}_{2} \mathrm{O}$ total, serta KTK yang sangat rendah. Status kesuburan tanah pada titik pengamatan jarak $500 \mathrm{~m}$ sampai dengan $1.000 \mathrm{~m}$ tergolong rendah dengan faktor pembatas berupa rendahnya $\mathrm{KTK}, \mathrm{KB}, \mathrm{P}$ total dan $\mathrm{K}_{2} \mathrm{O}$ total. Status kesuburan tanah pada titik pengamatan jarak $1.250 \mathrm{~m}$ sampai dengan $1.500 \mathrm{~m}$ tergolong sedang dengan faktor pembatas berupa rendahnya $\mathrm{KB}$ dan $\mathrm{P}_{2} \mathrm{O}_{5}$ total sedang.

Keseimbangan unsur hara merupakan hal yang sangat penting, dimana ketersediaan suatu unsur hara bisa menjadi tidak begitu berarti tanpa ketersediaan unsur hara yang lain, oleh sebab perbaikan status kesuburan tanah perlu dilakukan. Untuk memperbaiki status kesuburan tanah dilakukan dengan memperbaiki faktor pembatasnya. Dengan memperhatikan status masing-masing parameter kesuburan tanah dan hasil penetapan status kesuburan tanah yang ada pada masingmasing transek pengamatan maka dapat digunakan sebagai arahan tindakan pengelolaannya. Faktor pembatas yang ditemukan pada masing-masing titik transek pengamatan perlu menjadi fokus bagi pengelolaan kesuburannya. Rendahnya KB dapat ditingkatkan dengan penambahan kationkation basa seperti dengan pemberian kapur atau abu sisa bakaran. Rendahnya $\mathrm{P}_{2} \mathrm{O}_{5}$ total dan $\mathrm{K}_{2} \mathrm{O}$ total dapat ditingkatkan dengan penambahan berbagai jenis pupuk pembawa $\mathrm{P}_{2} \mathrm{O}_{5}$ dan $\mathrm{K}_{2} \mathrm{O}$. Rendahnya KTK dapat ditingkatkan dengan penambahan kandungan bahan organik tanah atau dengan peningkatan $\mathrm{pH}$ tanah melalui pengapuran dengan menggunakan kapur kalsit $\left(\mathrm{CaCO}_{3}\right)$ atau dolomit $\left(\mathrm{CaMg}\left(\mathrm{CO}_{3}\right)_{2}\right.$. 
Tabel 2. Hasil Penetapan Status Kesuburan Tanah di Desa Bajarum, Kecamatan Kota Besi Kabupaten Kotawaringin Timur, Kalimantan Tengah.

\begin{tabular}{|c|c|c|c|c|c|c|c|c|c|c|c|}
\hline \multirow{2}{*}{$\begin{array}{c}\text { Jarak } \\
\text { sampel dari } \\
\text { pinggir sungai }\end{array}$} & \multicolumn{10}{|c|}{ Parameter Kesuburan Tanah dan Statusnya } & \multirow{3}{*}{$\begin{array}{c}\text { Status } \\
\text { Kesuburan } \\
\text { Tanah }\end{array}$} \\
\hline & \multicolumn{2}{|c|}{$\begin{array}{c}\text { KTK } \\
(\mathrm{cmol}(+) / \mathrm{kg})\end{array}$} & \multicolumn{2}{|c|}{$\begin{array}{l}\mathrm{KB} \\
(\%)\end{array}$} & \multicolumn{2}{|c|}{$\begin{array}{c}\mathrm{C}- \\
\text { Organik } \\
(\%)\end{array}$} & \multicolumn{2}{|c|}{$\begin{array}{c}\mathrm{P}_{2} \mathrm{O} 5 \\
(\mathrm{mg} / 100 \mathrm{~g})\end{array}$} & \multicolumn{2}{|c|}{$\begin{array}{c}\mathrm{K}_{2} \mathrm{O} \\
(\mathrm{mg} / 100 \mathrm{~g})\end{array}$} & \\
\hline $250 \mathrm{~m}$ & 3,16 & SR & 1,18 & $\mathrm{R}$ & 17,30 & $\mathrm{~T}$ & 10,07 & $\mathrm{R}$ & 16,03 & $\mathrm{R}$ & \\
\hline $500 \mathrm{~m}$ & 8,87 & $\mathrm{R}$ & 1,97 & $\mathrm{R}$ & 14,99 & $\mathrm{~T}$ & 16,98 & $\mathrm{R}$ & 24,89 & $\mathrm{R}$ & $\mathrm{R}$ \\
\hline $750 \mathrm{~m}$ & 11,30 & $\mathrm{R}$ & 2,52 & $\mathrm{R}$ & 12,12 & $\mathrm{~T}$ & 19,47 & $\mathrm{R}$ & 31,41 & $\mathrm{~S}$ & $\mathrm{R}$ \\
\hline $1.000 \mathrm{~m}$ & 21,60 & $S$ & 7,22 & $\mathrm{R}$ & 10,61 & $\mathrm{~T}$ & 24,01 & $\mathrm{~S}$ & 42,41 & $\mathrm{~T}$ & $\mathrm{R}$ \\
\hline $1.250 \mathrm{~m}$ & 30,42 & $\mathrm{~T}$ & 10,75 & $\mathrm{R}$ & 8,40 & $\mathrm{~T}$ & 28,49 & $\mathrm{~S}$ & 47,81 & $\mathrm{~T}$ & $S$ \\
\hline $1.500 \mathrm{~m}$ & 31,38 & $\mathrm{~T}$ & 14,25 & $\mathrm{R}$ & 4,68 & $\mathrm{~T}$ & 33.17 & $\mathrm{~S}$ & 5270 & $\mathrm{~T}$ & $\mathrm{~S}$ \\
\hline
\end{tabular}

Keterangan: $\mathrm{T}=$ tinggi, $\mathrm{S}=$ sedang, $\mathrm{R}=$ rendah, $\mathrm{SR}=$ sangat rendah.

\section{KESIMPULAN}

Berdasarkan hasil penelitian ini dapat disimpulkan sebagai berikut:

1) Tanah pasang surut di Desa Bajarum, Kecamatan Kota Besi, Kabupaten Kotawaringin Timur, Provinsi Kalimantan Tengah tergolong tanah masam (dengan kisaran $\mathrm{pH}$ 4,45 - 4,93), kandungan Al-dd berkisar antara $0,12-0,35 \mathrm{cmol}(+) / \mathrm{kg}$, nilai KTK tinggi $(2,57 \quad-31,38$ $\mathrm{cmol}(+) / \mathrm{kg})$, nilai $\mathrm{KB}$ sangat rendah $(1,8$ $19,74 \%)$, kandungan $\mathrm{P}_{2} \mathrm{O} 5$ total sedang (8,05 - 33,17 me/100g), kandungan $\mathrm{K}_{2} \mathrm{O}$ total tinggi $(10,06-52,70 \mathrm{mg} / 100 \mathrm{~g})$, kandungan C-organik sangat tinggi $(6,09-14,12 \%)$, kandungan $\mathrm{N}$ total sedang $(0,03-0,23 \%)$ dan kandungan $\mathrm{H}-$ dd berkisar antara $1,24-2,66 \mathrm{cmol}(+) / \mathrm{kg}$.

2). Semakin jauh jarak tanah dari posisi pinggir sungai Mentaya menunjukkan adanya peningkatan $\mathrm{C}$ organik, $\mathrm{P}_{2} \mathrm{O}_{5}$ total, $\mathrm{N}$ total, $\mathrm{K}_{2} \mathrm{O}$ total, $\mathrm{pH}$, KTK dan $\mathrm{KB}$ dan status kesuburan tanah. Sebaliknya menunjukkan adanya penurunan kandungan $\mathrm{Al}-\mathrm{dd}$ dan $\mathrm{H}$-dd. Faktor pembatas kesuburan tanah terutama berupa rendahnya kejenuhan basa, disamping itu pada beberapa titik pengamatan juga disebabkan karena rendahnya $\mathrm{KTK}, \mathrm{P}_{2} \mathrm{O}_{5}$ total dan $\mathrm{K}_{2} \mathrm{O}$ total.

3) Tanah lapisan bawah (25 - 50) $\mathrm{cm}$ mempunyai nilai $\mathrm{pH}$ dan $\mathrm{KB}$ lebih tinggi dibandingkan dengan tanah lapisan atas (0 - 25) $\mathrm{cm}$. Sebaliknya tanah lapisan atas mempunyai nilai KTK, Al-dd, H-dd,
$\mathrm{P}_{2} \mathrm{O} 5$ total, $\mathrm{K}_{2} \mathrm{O}$ total, $\mathrm{N}$ total dan $\mathrm{C}$ organik lebih tinggi dibandingkan dengan tanah lapisan bawah.

\section{UCAPAN TERIMA KASIH}

Ucapan terima kasih disampaikan kepada Bpk Kundori yang telah turut membantu dalam kegiatan penelitian dan penulisan jurnal ilmiah ini.

\section{DAFTAR PUSTAKA}

Adhi, W., Nugroho, K. Alkasuma, Pahidi, Wahyu Wahdini, Abdurachman, H.Suhardjo. 1992. Lahan Pasang Surut. http;//Pengetahuan Umum. Net/ Lahan-Pasang-Surut/ (diakses 21 Februari 2016.

Angelova, V. R., Akova, V. I., Artinova, N. S. and Ivanov, K. I. 2013. The effect of organic amendments on soil chemical characteristics. Bulg.J.Agric.Sci., 19: 958-971.

Audu, M. and Aiyu, Z. 2013. Analysis of nutrient content of some organic materials for soil amendment in Sakoto Metroplis, Nigeria. Journal of Biology. Agriculture and Hea lthcare Vol.3, No.18

Basuki, Priatmadi, B.J., Yanuwiadi B. and Soemarno, 2014. Layer DepthsBased Soil Chemical Properties On Oil Palm Area In East Kotawaringin, Central Borneo. Journal of Environment and Earth Science IISTE (The International Institute for 
Science, Technology and Education). 4 (9): 18-24

Hardjowigeno, S. 1992. Ilmu Tanah (3th Ed.). Mediyatama Sarana Perkasa. Jakarta. 233p.

Manwan, I., Ismail, I.G., Alihamsyah, T., dan Partohardjono. 1992. Teknologi Pengembangan Pertanian Lahan Rawa Pasang Surut. Dalam : Prosiding Pertemuan Nasional Pengembangan Teknologi Pertanian Lahan Rawa Pasang Surut dan Lebak, Cisarua 7 - 9 Maret 1992.

Murphy, B.W. 2015. Impact of soil organic matter on soil properties - a review with emphasis on Australian soils. Soil Research 53(6) 605-635 https://doi.org/10.1071/SR14246.

Nduwumuremyi, A., Rugansu, V., Mugwe, J. N. and Rusangawa, A. C. 2013. Effects of unburned lime on soil $\mathrm{pH}$ and base cations in acidic soil. ISRN Soil Science.

Noor, M. 2007. Rawa Lebak: Ekologi, Pemanfaatan, dan Pengembangannya. Raja Grafindo Persada. Jakarta.

Nweke, I. A. and Nsoanya, L. N. 2013. Soil pH an indices for effective management of soils for crop production. International Journal of Scientific \& Technology Research. 2 (3): 132-134.

Nyarko, F. O. 2012. Ameleorating soil acidity in Ghana: a concise review of approaches. ARPN Jounal of Science and Technology, 2: 143-153.

Purwanto, B.H., Ken-ichi Kakuda, Ho Ando, Jong Foh Shoon, Yoshinori Yamamoto, Akira Watanabe \& Tetsushi Yoshida, 2002. Nutrient availability and response of sago palm (Metroxylon sagu Rottb.) to controlled release $\mathrm{N}$ fertilizer on coastal lowland peat in the tropics. Soil Sci. Plant Nutr . 48 (4), 529-537, DOI: 10.1080/00380768.2002.10409235
Rezig, A. M. R., Elhadi, E. A. and Mubarak, A. R. 2012. Effect of incorporation of some wastes on a wheat-guar rotation system on soil physical and chemical properties. International Journal of Recycling of Organik Waste in Agriculture, 1:1. doi:10.1186/22517715-1-1.

Staf Pusat Penelitian Tanah. 1983. Term of Reference Klasifikasi Kesesuaian Lahan. Proyek Penelitian Pertanian Menunjang Transmigrasi (P3MT).

Stevenson, F.J. 1982. Humus Chemistry. Genesis, Composition, Reaction. John Wiley and Sons Inc. New York, Chichester, Brisbane, Toronto, Singapore.

Syekhfani. 2010. Hubungan Hara Tanah Air dan Tanaman. ITS press.

Tan, K.H.. 1982. Principles of Soil Chemistry. Marcel Dekker, Inc. New York. Tester,

Tisdale, S.L, Nelson, E. L., Beaton, J. D. and Havlin, J. L. 1999. Soil Fertility and Fertilizers an Introduction to Nutrient Management. Sixth Edition. Macmillan Publishing Company.

Whitley, A.E., J.L. Moir, P.C. Almond and D.J. Moot. 2016. Soil $\mathrm{pH}$ and exchangeable aluminium in contrasting New Zealand high and hill country soils. Hill Country Grassland Research and Practice Series 16: 169-172. 